\title{
RESPON LINTAH LAUT (Zeylanicobdella arugamensis) TERHADAP SALINITAS BERBEDA SECARA LABORATORIUM
}

\author{
Ketut Mahardika ${ }^{a}$, Indah Mastuti ${ }^{a}$, dan Zafran ${ }^{a}$ \\ ${ }^{a}$ Balai Besar Riset Budidaya Laut dan Penyuluhan Perikanan, Desa Penyabangan, Kec. Gerokgak, kab. \\ Buleleng, Bali, Indonesia \\ *Corresponding author: kmahardika@yahoo.com
}

\begin{abstract}
Abstrak
Infeksi lintah laut (hirudinea, Zeylanicobdella arugamensis) pada ikan kerapu dapat menimbulkan luka di bekas tempat menempelnya. Infeksi lintah juga dapat menurunkan daya tahan ikan terhadap infeksi mikroorganisme lainnya. Penelitian ini bertujuan untuk mengetahui respon lintah laut dan telurnya untuk hidup pada media dengan salinitas berbeda. Penelitian dilakukan secara laboratorium dengan menempatkan lintah laut pada cawan petri (diameter $8 \mathrm{~mm}$ ). Sekitar 10-67 ekor lintah laut hidup ditempatkan dalam setiap satu cawan petri yang telah diisi air laut (salinitas $32 \mathrm{ppt}$ ). Lintah laut tersebut diinkubasi pada suhu ruang $\left(29-31^{\circ} \mathrm{C}\right)$ selama 2 hari agar lintah bertelur dalam cawan petri. Selanjutnya, masing-masing cawan petri diganti airnya dengan air laut yang telah di saring (kertas saring $1 \mu \mathrm{m}$ ) dengan salinitas: 30, 25, 20, 15, 10, 5 dan 0 ppt. Air pemeliharaan lintah laut diganti setiap dua hari sekali dengan air baru dengan salinitas yang sama. Lintah laut dan telunya diinkubasi pada suhu ruang selama 11 hari, Hasil pengamatan menunjukkan bahwa lintah laut dapat bertahan hidup pada salinitas 5 sampai 30 ppt selama 11 hari, walaupun jumlahnya menurun $(3,9-73,1 \%)$. Demikian pula dengan telur lintah, dapat berkembang dan menetas pada hari ke $9-$ $11(2,6-47,4 \%)$ setelah diinkubasi di salinitas 5-30 ppt. Hasil tersebut menunjukkan bahwa lintah laut dan telurnya dapat hidup dan menetas pada media pemeliharaan air laut sampai air payau.
\end{abstract}

Kata Kunci: lintah laut, respon, salinitas

\begin{abstract}
Sea leech infections (hirudinea, Zeylanicobdella arugamensis) in groupers has been caused injury in the former place of sticking. Leech infection could reduce fish resistance to other microorganism infections. The aims of this study was to determine the response of sea leeches and their eggs to live on media with different salinity. The study was conducted in a laboratory by placing sea leeches on petri dishes (diameter $8 \mathrm{~mm}$ ). About 10-67 live sea leeches are placed in each petri dish that has been filled with sea water (32 ppt salinity). The sea leech was incubated at room temperature $\left(29-31{ }^{\circ} \mathrm{C}\right)$ for 2 days to give leeches an opportunity to lay eggs in petri dishes. Furthermore, sea water in each petri dish was replaced with filtered sea water (1 $4 \mathrm{~m}$ filter paper) with salinity: 30, 25, 20, 15, 10, 5 and 0 ppt. Incubation water was exchanged every two days with new water with the same salinity. The sea leech and it eggs were incubated at room temperature for 11 days. The results showed that sea leeches could survived in salinity of 5 to 30 ppt for 11 days, although the number decreased (3.9-73.1\%). Likewise with sea leech eggs, it could developed and hatched on days 9 - 11 (2.6-47.4\%) after incubation in salinity of 5-30 ppt. These results indicate that sea leeches and its eggs can live and hatch on the maintenance of sea water to brackish water.
\end{abstract}

Keywords: sea leech, response, salinity

\section{PENDAHULUAN}

Infeksi lintah (hirudinea) pada ikan budidaya dapat menimbulkan kerugian bagi pembudidaya karena dapat menghambat pertumbuhan ikan. Lintah memperoleh makanan dengan cara menghisap darah dari inangnya (ikan). Lintah laut dapat menginfeksi beberapa jenis ikan kerapu seperti kerapu lumpur (Epinephelus coioides), kepau macan (E. fuscoguttatus), kerapu batik (E. polyphekadion), kerapu bebek (Cromileptes altivelis), napoleon (Cheilinus undulatus), kerapu sunu (Plectropomus leopardus), kerapu hibrida cantang dan kerapu hibrida cantik [1]-[4]. Spesies lintah yang 
menginfeksi kerapu hibrida termasuk ke dalam spesies Zeylanicobdella arugamensis (famili: Pisciolidae) [3], [5].

Ikan yang terinfeksi menunjukkan gejala berenang lemah di kolom dan atau di permukaan air. Bahkan ikan yang terinfeksi berat atau badannya dipenuhi lintah menunjukkan gejala diam di dasar jaring atau bak pemeliharaan dengan kondisi sangat lemah dan terlihat seperti berbulu tebal. Lintah tersebut lebih banyak ditemukan menempel pada sirip (punggung, belakang, dan perut), ekor, operkulum insang, rongga mulut, dan perut bagian bawah. Infeksi lintah menimbulkan sirip ikan menjadi geripis, kemerahan, dan pembengkakan pada kulit ikan [6]. Patogenisitas dari lintah ini rendah, tetapi infeksi berat dapat menimbulkan luka pada kulit sehingga memberi peluang adanya infeksi sekunder oleh bakteri atau parasit lainnya [1]. Lintah tersebut menempel sangat kuat pada tubuh inangnya. Lintah yang sudah dewasa akan bermigrasi atau melepas diri dari inangnya dan menempel pada bak atau peralatan pemeliharaan untuk bertelur. Siklus hidup telur sampai menetas dan menjadi lintah dewasa membutuhkan waktu 17-22 hari [3], [4], [7]. Namun siklus hidup lintah tersebut dapat lebih pendek waktunya jika lintah dipelihara dengan air mengalir [4].

Keberadaan lintah di perairan laut di Bali Utara masih menjadi kendala utama bagi pembudidaya ikan kerapu di hatcheri maupun di keramba jaring apung (KJA). Lintah tersebut selalu ada dan menginfeksi ikan kerapu sepanjang tahun terutama pada induk kerapu yang dipelihara di bak induk di hatcheri yang menggunakan air laut langsung dan ikan kerapu yang dipelihara di KJA. Treatmen terhadap lintah ini dapat dilakukan dengan perendaman dalam formalin 200-250 ppm selama 1 jam $[1,4]$. Pemakaian formalin dengan konsentrasi tinggi dapat mengganggu pernafasan ikan, oleh karena itu diperlukan aerasi yang kuat dalam treatmen tersebut [1]. Namun demikian, treatmen induk dan ikan kerapu di KJA lebih banyak menggunakan air tawar. Penggunaan air tawar dipandang aman karena treatmen dilakukan hampir 5-7 hari sekali. Perendaman pun dilakukan hanya sebentar (kurang dari setengah jam) diikuti dengan pengurutan tubuh ikan dengan tangan untuk membantu melepaskan lintah. Cara tersebut mampu mengurangi beban infeksi lintah dan ektoparasit lain pada ikan kerapu tanpa menimbulkan stres berat akibat bahan kimia. Namun demikian sangat perlu diketahui respon lintah terhadap air tawar maupun air payau, karena sewaktu habis treatmen air tawar penampungan lintah sering dibuang kembali ke saluran pembuangan atau ke laut. Demikian pula pada benih ikan kerapu dari hatcheri yang ditebar ke tambak (pemeliharaan dengan air payau) terkadang tidak melalui treatmen ektoparasit terlebih dahulu, sehingga sering membawa lintah ke tambak. Penelitian ini bertujuan untuk mengetahui respon lintah laut dan telurnya untuk hidup pada media dengan salinitas berbeda secara laboratorium. Sehingga nantinya dapat dijadikan rujukan dalam penanganan lintah pada ikan kerapu.

\section{MATERIAL AND METHOD}

\section{Tempat penelitian dan asal lintah}

Penelitian dilakukan di Balai Besar Riset Budidaya Laut dan Penyuluhan Perikanan (BBRBLPP), Gondol-Bali, pada bulan JuliAgustus 2018. Lintah diisolasi dari ikan kerapu hibrida cantang (Panjang total: 14-17 $\mathrm{cm}$ ) yang dipeliharan di bak beton (volume 500 L) di Laboratorium Patologi, BBRBLPP. Lintah diisolasi dengan cara merendam ikan yang terinfeksi lintah dalam air tawar selama 15 menit. Lintah-lintah yang terlepas dari tubuh ikan dan yang masih menempel di tubuh ikan diambil dengan tangan dan ditampung ke dalam cawan petri (diameter 8 $\mathrm{mm})$.

\section{Perlakuan salinitas}

Isolasi lintah dari ikan kerapu menggunakan air tawar menyebabkan beberapa lintah lemah dan mati setelah ditempatkan dalam cawan petri yang berisi air laut. Pada percobaan ini, lintah-lintah yang lemah dan mati dibuang dengan membilas air laut di cawan petri dengan air laut baru sebanyak 3 kali, sehingga lintah-lintah yang 
masih hidup dan menempel pada cawan petri yang digunakan dalam penelitian ini. Perlakuan salinitas dilakukan dengan dua ulangan waktu. Pertama, setiap perlakuan salinitas menggunakan 2 cawan petri (2 ulangan cawan petri), demikian pula pada ulangan perlakuan kedua menggunakan masing-masing dua cawan petri. Sekitar 10-67 ekor lintah laut hidup ditempatkan dalam setiap satu cawan petri yang telah diisi air laut (salinitas 32 ppt). Lintah laut tersebut diinkubasi pada suhu ruang $\left(29-31^{\circ} \mathrm{C}\right)$ selama 2 hari agar lintah bertelur dalam cawan petri. Selanjutnya, masing-masing cawan petri diganti airnya dengan air laut yang telah di saring (kertas saring $1 \mu \mathrm{m})$ dengan salinitas: $30,25,20,15,10,5$ dan 0 ppt. Air pemeliharaan lintah laut diganti setiap dua hari sekali dengan air baru dengan salinitas yang sama. Lintah laut dan telunya diinkubasi pada suhu ruang selama 11 hari. Suhu dan salinitas air pemeliharaan lintah diukur setiap dua hari sekali pada pagi hari sekitar jam 09.00-10.00 wita.

\section{Pengamatan lintah dan telurnya}

Pemgamatan terhadap respon lintah dan telurnya dilakukan secara makroskopis dan mikroskopis. Lintah yang hidup dihitung di setiap perlakuan, demikian pula jumlah larva yang menetas selama 11 hari dihitung di semua perlakuan salinitas. Hasil pengamatan disajikan dalam gambar dan tabel.

\section{HASIL DAN PEMBAHASAN}

Hasil pengamatan suhu dan salinitas air pemeliharaan lintah dalam cawan petri seperti tertera dalam Tabel 1.

Tabel 1. Suhu dan salinitas air selama pemeliharaan lintah dalam cawan petri.

\begin{tabular}{ccc}
\hline $\begin{array}{c}\text { Perlakuan } \\
\text { Salinitas (ppt) }\end{array}$ & Suhu $\left({ }^{\circ} \mathrm{C}\right)$ & $\begin{array}{c}\text { Salinitas } \\
(\mathrm{ppt})\end{array}$ \\
\hline 30 & $27,8-28,1$ & $30-31$ \\
\hline 25 & $27,8-28,0$ & $25-26$ \\
\hline 20 & $27,8-28,1$ & $20-21$ \\
\hline 15 & $27,7-28,0$ & $15-16$ \\
\hline
\end{tabular}

\begin{tabular}{ccc}
\hline 10 & $27,5-27,8$ & $10-11$ \\
\hline 5 & $27,5-27,8$ & $5-6$ \\
\hline 0 & $27,5-27,7$ & 0 \\
\hline
\end{tabular}

Pada Tabel 1 terlihat suhu air pemeliharaan lintah dalam cawan petri berkisar antara 27,0$28,0^{\circ} \mathrm{C}$. Suhu pada air dengan salinitas tinggi sedikit lebih tinggi $\left(0,3{ }^{\circ} \mathrm{C}\right)$ dibandingkan dengan air salinitas rendah. Hal tersebut kemungkinan dipengaruhi oleh volume air dalam cawan petri maupun salinitas air. Sedangkan salinitas air pemeliharaan lintah yang di desain seperti pada perlakuan, namun setelah dilakukan pemeliharaan lintah terjadi kenaikan salinitas (rentang $1 \mathrm{ppt}$ ).

Pengamatan mikroskopis menunjukkan bahwa lintah yang dipelihara dengan air tawar (salinitas 0 ppt) terjadi kematian di hari kedua dan ketiga (Gambar 1A). Demikian pula telur yang dihasilkan tidak mengalamai perkembangan atau tidak menetas sampai akhir penelitian (Gambar 1B). Akan tetapi lintah yang dipelihara dalam air dengan salinitas 5 ppt menunjukkan adanya beberapa lintah yang masih hidup sampai hari ketiga (Gambar 1C). Lintah-lintah tersebut masih menempel dengan kuat di dasar dan di sisi dalam cawan petri. Pada hari ke-7, lintahlintah yang masih hidup menunjukkan adanya gelembung bening pada kulit luarnya dan hampir di setiap ruas tubuhnya (Gambar 1D). Hal tersebut kemungkinan respon dari lintah terhadap salinitas rendah. Lintah dilaporkan hidup di berbagai lingkungan yang sering terkena fluktuasi ekstrim seperti fluktuasi konsentrasi oksigen dan suhu [8]. Lebih lanjut dilaporkan bahwa banyak spesies lintah mampu beradaptasi dengan perubahan salinitas, suhu, konsentrasi oksigen, dan kondisi lingkungan lainnya karena plastisitas fisiologis dari lintah yang cukup besar. Perbedaan lingkungan salinitas yang ekstrim menyebabkan lintah membutuhkan energi ekstra dan kadar oksigen yang tinggi. Ketika kadar oksigen kurang, lintah air akan beradaptasi dengan cara ventilasi permukaan tubuhnya melalui undulasi (membentuk gelembung udara) di dorsoventral tubuhnya. Pada saat yang sama alat penghisap melekat erat pada substrat. Undulasi ini bertujuan untuk memindahkan air di sepanjang tubuh 
lintah, dan mirip dengan gerakan berenang beberapa spesies lintah tanpa alat penghisap. Pada keadaan ini, lintah laut yang dipelihara pada air salinitas 5 ppt masih mampu bertahan hidup sampai akhir penelitian. Sedangkan calon embrio dalam telur lintah masih dapat berkembang dan menetas menjadi larva lintah baru (insert Gambar 1D).

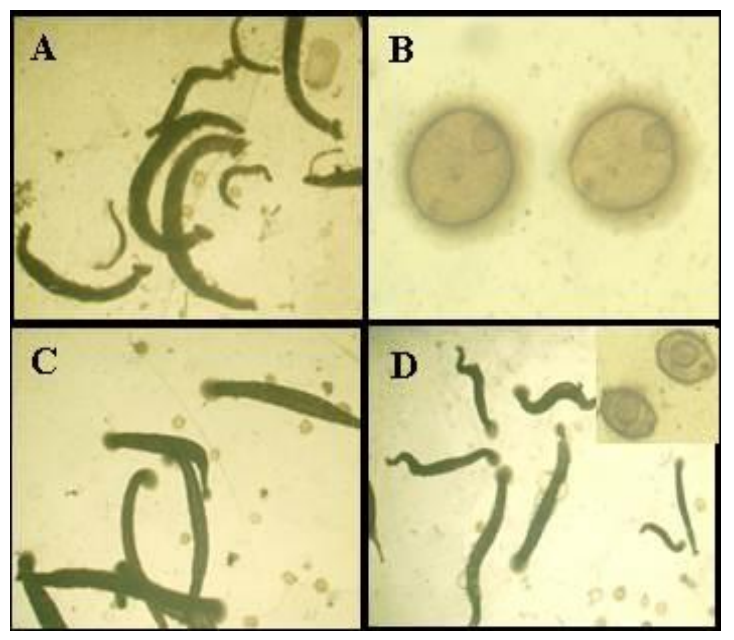

Gambar 1. A). Lintah yang dipelihara dalam air tawar (salinitas $0 \mathrm{ppt}$ ) pada hari ketiga menunjukkan kematian (10x). B). Telur lintah yang dipelihara dalam air tawar pada hari ke-11 tidak menunjukkan adanya perkembangan embrio (80x). C). Lintah yang dipelihara dalam air salinitas 5 ppt pada hari ketiga masih hidup dan menempel pada cawan petri (10x). D). Lintah yang dipelihara dalam air salinitas 5 ppt pada hari ke-9, kulit luarnya terlihat menggelembung seperti balon (10x). Insert: telur lintah yang dipelihara dalam air salinitas 5 ppt pada hari ketiga menunjukkan adanya perkembangan ke tahap gastrula.

Lintah laut yang dipelihara dalam air bersalinitas 10-30 ppt memiliki respon positif, dimana lintah-lintah tersebut dapat bertahan hidup sampai 11 hari (Gambar 2A). Lintah laut dilaporkan mampu bertahan hidup tanpa inang sampai 2 minggu (14 hari) pada lingkungan hidupnya [3]. Hal yang sama juga ditunjukkan pada telur lintah yang dipeliharan dalam air bersalinitas 10-30 ppt. Embrio di dalam telur-telur lintah tersebut berkembang dengan baik (Gambar 2B, C, D). Telur lintah laut berkembang menjadi morula, blastula, dan gastrula dalam lima hari. Awal fase embrio terjadi pada hari ke-6 dan selanjutnya embrio terus mengalami perkembangan dan gerakannya semakin aktif. Embrio-embrio tersebut akan menetas menjadi larva lintah pada hari ke-10 sampai 11 [3, 4, 7]. Lingkungan air pemeliharaan lintah dan telurnya pada salinitas $10-15 \mathrm{ppt}$ terlihat lebih bersih dengan sedikit adanya mikroorganisme air yang mengerumuni lintah maupun telunya (Gambar 2B). Sedangkan lingkungan air pemeliharaan lintah dan telurnya pada salinitas 0-5 ppt (Gambar 1 B, D) dan salinitas 20-30 ppt (Gambar 2 C, D) lebih banyak mikroorganisme air yang mengelilingi sisa tubuh lintah yang mati dan telur lintah. Hal tersebut diduga mikroorganisme tersebut merupakan miroorganisme air laut dan air tawar. Oleh karena air laut dan air tawar yang digunakan untuk memelihara lintah dan telurnya berasal dari air yang di filter menggunakan membran fiter $10 \mu \mathrm{m}$, sehingga mikroorganisme masih ada yang ikut dalam air. Pada salinitas 10-15 ppt kemungkinan merupakan salinitas peralihan dan kemungkinan ekstrim bagi mikroorganisme air sehingga perkembangannya lebih sedikit.

Hasil perhitungan lintah yang dipelihara dengan salinitas berbeda menunjukkan bahwa tidak semua lintah mampu bertahan hidup sampai 11 hari pemeliharaan. Sebagian besar lintah mati dan hanya sedikit lintah yang bertahan hidup dengan kondisi tubuh semakin kurus (Tabel 2). Pada percobaan pertama, persentase lintah yang masih hidup pada salinitas 25 dan $30 \mathrm{ppt}$ lebih sedikit $(11,4-$ $12,1 \%)$ dibandingkan dengan persentase lintah yang bertahan hidup pada salinitas 10 20 ppt (26,2-30\%). Sedangkan lintah yang bertahan hidup pada salinitas 5-6 ppt hanya 3,9\%. Akan tetapi, lintah-lintah laut tersebut tidak dapat hidup di air tawar. Pada tabel 2 juga menunjukkan bahwa telur lintah masih ada dan dapat berkembang menjadi larva pada salinitas 5-30 ppt, walaupun persentase jumlahnya bervariasi $(9,3-23,5 \%)$. Tidak 
semua telur yang dihasilkan oleh lintah laut dapat menetas. Jumlah telur yang mampu dihasilkan oleh induk lintah berkisar antara 163 butir dan hanya mampu menetas menjadi larva berkisar antara 2,7-100\% [3].

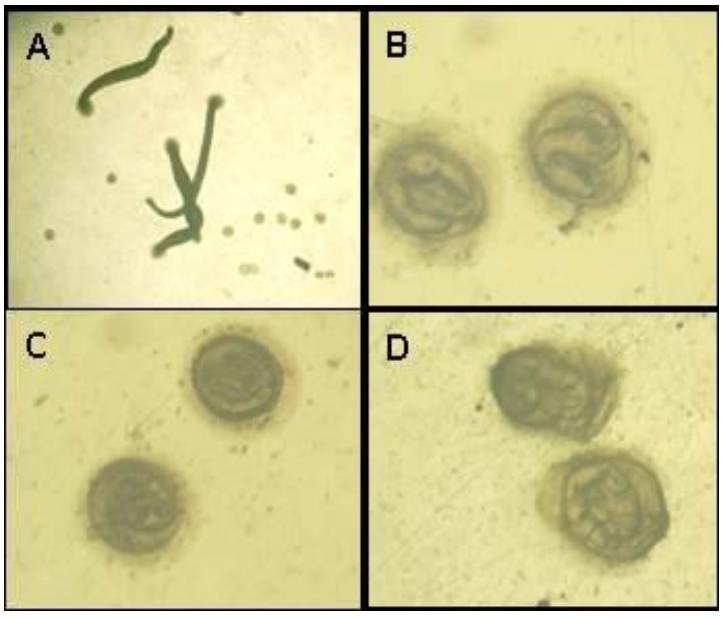

Gambar 2. A). Lintah yang dipelihara dalam air salinitas 15 ppt pada hari ke-10 masih mampu bertahan hidup dan menempel pada cawan petri (10x). B). Telur lintah yang dipelihara dalam air salinitas $10 \mathrm{ppt}$ pada hari ke-7 menunjukkan perkembangan phase embrio (80x). C). Telur lintah yang dipelihara dalam air salinitas 20 ppt pada hari ke-8 menunjukkan embrio mulai aktif bergerak (80x). D). Telur lintah yang dipelihara dalam air salinitas 25 ppt pada hari ke-9 menunjukkan gerakan embrio lebih. Pada dasar cawan petri terlihat lebih banyak mikroorganisme yang mengganggu perkembangan telur (80x).

Pada percobaan kedua, Persentase lintah yang bertahan hidup sampai 11 hari pemeliharaan pada salinitas 5-30 ppt bervariasi (17,773,1\%). Persentase ini lebih tinggi dibandingkan dengan percobaan pertama. Namun, persentase daya tetas telur lintah menjadi larva lebih rendah 2,6-12,9\%) dibandingkan dengan percobaan pertama. Hal yang sama terjadi pada percobaan pertama dan kedua, dimana lintah laut dan telurnya dengan pemeliharaan air tawar tidak mampu beradaptasi untuk hidup dan menetas menjadi larva.

Tabel 2. Jumlah rata-rata lintah dan telurnya pada percobaan pertama yang masih hidup dan menetas setelah 11 hari pemeliharaan dengan salinitas berbeda.

\begin{tabular}{ccccc}
\hline \multirow{2}{*}{$\begin{array}{c}\text { Salinita } \\
\text { s (ppt) }\end{array}$} & \multicolumn{2}{c}{$\begin{array}{c}\text { Jumlah rata- } \\
\text { rata awal }\end{array}$} & $\begin{array}{c}\text { Jumlah rata-rata setelah 11 } \\
\text { hari inkubasi }\end{array}$ \\
\cline { 2 - 5 } Lintah & Telur & Lintah hidup & Larva \\
\hline $30-31$ & 44 & 38 & $5(11,4 \%)$ & $\begin{array}{c}7 \\
(18,4 \%)\end{array}$ \\
\hline $25-26$ & 33 & 34 & $4(12,1 \%)$ & $\begin{array}{c}8 \\
(23,5 \%)\end{array}$ \\
\hline $20-21$ & 42 & 31 & $11(26,2 \%)$ & $\begin{array}{c}4 \\
(12,9 \%)\end{array}$ \\
\hline $15-16$ & 10 & 17 & $3(30 \%)$ & $\begin{array}{c}3 \\
(17,7 \%)\end{array}$ \\
\hline $10-11$ & 24 & 15 & $7(29,2 \%)$ & $\begin{array}{c}2 \\
(13,3 \%)\end{array}$ \\
\hline $5-6$ & 51 & 54 & $2(3,9 \%)$ & $5(9,3 \%)$ \\
\hline 0 & 30 & 35 & $0(0 \%)$ & $0(0 \%)$ \\
\hline
\end{tabular}

Hasil penelitian sebelumnya melaporkan bahwa persentase penetasan lintah dewasa tertinggi pada salinitas 30 ppt $(32,52,8 \%)$ diikuti oleh $20 \mathrm{ppt}(18,04,3 \%)$ dan $10 \mathrm{ppt}$ (12,1 1,4\%). Lintah dewasa dan lintah kecil dapat hidup hingga kisaran rata-rata 4-7 hari di salinitas mulai dari 10 hingga 40 ppt [9]. Lebih lanjut dilaporkan bahwa pengaturan osmotik lintah laut tidak tergantung hanya pada inangnya saja tapi juga pada air sekitarnya. Salinitas memiliki beberapa efek pada osmoregulasi dan hal tersebut tergantung pada inang atau media sekitarnya. Beberapa spesies, misalnya, ditemukan dalam kondisi payau saja, sementara yang lain dapat dibunuh dengan memandikan ikan di air payau [10]. Fluktuasi dalam salinitas antara 1 dan 3 ppt biasanya terlihat di air tropis selama hujan lebat. Jika rata-rata persentase daya tetas telur adalah $60 \%$ di lingkungan tropis alami dengan salinitas mulai dari 26 hingga 30 ppt dan pada suhu air 26 hingga $30^{\circ} \mathrm{C}$. Hal tersebut dipercaya bahwa lebih banyak generasi lintah laut bisa bertahan hidup dan dapat menyebabkan potensi risiko yang lebih tinggi dari infestasi lintah laut pada spesies budidaya tropis. Ketika lintah laut menempel pada 
inang, dia dapat beradaptasi dengan pengurangan salinitas (10-30 ppt) dari air di sekitarnya [9].

Tabel 3. Jumlah rata-rata lintah dan telurnya pada percobaan kedua yang masih hidup dan menetas setelah 11 hari pemeliharaan dengan salinitas berbeda.

\begin{tabular}{ccccc}
\hline \multirow{2}{*}{$\begin{array}{c}\text { Salinitas } \\
(\mathrm{ppt})\end{array}$} & \multicolumn{2}{c}{$\begin{array}{c}\text { Jumlah rata-rata } \\
\text { awal }\end{array}$} & \multicolumn{2}{c}{$\begin{array}{c}\text { Jumlah rata-rata setelah } \\
\text { 11 hari inkubasi }\end{array}$} \\
\cline { 2 - 5 } & Lintah & Telur & $\begin{array}{c}\text { Lintah } \\
\text { hidup }\end{array}$ & Larva \\
\hline $30-31$ & 17 & 52 & $3(17,7 \%)$ & $3(5,8 \%)$ \\
\hline $25-26$ & 28 & 63 & $19(67,9 \%)$ & $3(4,8 \%)$ \\
\hline $20-21$ & 11 & 30 & $2(18,2 \%)$ & $2(6,7 \%)$ \\
\hline $15-16$ & 41 & 41 & $19(46,4 \%)$ & $5(12,2 \%)$ \\
\hline $10-11$ & 25 & 116 & $14(56,0 \%)$ & $\begin{array}{c}15 \\
(12,9 \%)\end{array}$ \\
\hline $5-6$ & 67 & 236 & $49(73,1 \%)$ & $6(2,6 \%)$ \\
\hline 0 & 45 & 152 & $0(0 \%)$ & $0(0 \%)$ \\
\hline
\end{tabular}

\section{KESIMPULAN}

Dari hasil penelitian tersebut dapat disimpulkan bahwa lintah laut dan telurnya dapat hidup dan menetas pada media pemeliharaan air laut sampai air payau (5-30 ppt). Namun persentase kelulushidupan lintah dan telurnya sampai hari ke-11 pada salinitas tersebut bervariasi $(2,9-56 \%$ dan $2,6-23,5 \%)$.

\section{UCAPAN TERIMAKASIH}

Penulis mengucapkan terimakasih kepada mahasiswa PKL yaitu Rizka Nadiyah dari Universitas Brawijaya, dan Siska Novianti dari Universitas Trunojoyo, serta teknisi litkayasa Laboratorium Patologi BBRBLPP yang telah membantu dalam penelitian ini.

\section{DAFTAR PUSATAKA}

[1] Koesharyani, D. Roza, K. Mahardika, F. Johnny, Zafran, \& K. Yuasa, "Manual for Fish Disease Diagnosis-II. Marine fish and crustacean diseases in Indonesia". Gondol Research Institute for Mariculture, Central Research Institute for Sea Exploration and Fisheries, Dep. of Marine Affair and Fisheries, and Japan International Cooperation Agency, p. 5-7, 2001.
[2] S. Kleinertz, \& H.W. Palm, "Parasites of the grouper fish Epinephelus coioides (Serranidae) as potential environmental indicators in Indonesian coastal ecosystems". Journal of Helminthology, 89, 86-99, 2013.

[3] K. Mahardika, I. Mastuti, Sudewi, \& Zafran, "Identification and life cycle of marine leech isolated from cultured hybrid grouper in the Northern Bali water of Indonesia". Indonesian Aquaculture Journal, 13 (1), 41-49, 2018

[4] Murwantoko, S.L.C. Negoro, A. Isnansetyo, \& Zafran, "Life cycle of marine leech (Zeylanicobdela arugamensis) from cultured cantik hybrid grouper (Ephinephelus sp.) and their susceptibility against chemicals". Aquacultura Indonesia, 18(2), 72-76, 2017.

[5] Murwantoko, S.L.C. Negoro, A. Isnansetyo, \& Zafran, "dentification of marine leech and assessment of its prevalence and intensity on cultured hybrid groupers (Epinephelus sp.)". Biodiversitas, 19(5), 1798-1804, 2018.

[6] E.R.C. Cruz-Lacierda, J.D. Toledo, \& E.M. Burreson, "Marine leech (Zeylanicobdella arugamensis) infestation in cultured orange-spotted grouper, Epinephelus coioides". Aquaculture, 185 (3-4), 191-196, 2000.

[7]. C. Kua, M.A. Azmi, \& N.K.A. Hamid, "Life cycle of the marine leech (Zeylanicobdella arugamensis) isolated from sea bass (Lates calcarifer) under laboratory conditions". Aquaculture, 302, 153-157, 2010.

[8] F.R. Govedich, W.E. Moser, \& R.W. Davies, "Annelida: Clitellata, Hirudinea, Euhirudinea". 
Freshwater Invertebrates of the Malaysian Region, 175-190, 1990.

[9] B.C. Kua, F.C. Choong, \&Y.Y. Leaw, "Effect of salinity and temperature on marine leech, Zeylanicobdella arugamensis (De Silva) under laboratory conditions. Journal of Fish Diseases, 37, 201-207, 2014

[10] M. Begon, J.L. Harper, \& C.R. Townsend, "Ecology: Individuals, Populations and Communities, 3rd Edn. pp. 45. Blackwell, Oxford, UK, 1995. 